\title{
UNDERSTANDING BOUNDARIES OF SPACES AND EACH OTHER: CONTEMPORARY ARTIST USED IN VISUAL ARTS ${ }^{1}$
}

\section{Ceren Tekin Karagöz}

Dr. Arş. Gör., Pamukkale Üniversitesi, Eğitim Fakültesi, Güzel sanatlar Eğitimi Bölümü, Resim-I̧ş Eğitimi Anabilim Dalı ckaragoz@pau.edu.tr, ORCID: 0000-0001-8718-9608

\section{İbrahim Karagöz}

Öğretmen, Milli Eğitim Bakanlığı1, ibrahimkaragoz04@gmail.com, ORCID: 0000-0001-6514-7802

Tekin Karagöz, Ceren; Karagöz, İbrahim. "Understanding Boundaries of Spaces and Each Other: Contemporary Artist Used in Visual Arts". idil, 85 (2021 Eylül): s. 1410-1419. doi: 10.7816/idil-10-85-10

\begin{abstract}
This visual essay focuses on how social media tools and contemporary artist influence learners and the course process as one of the methods used in visual arts lectures. Participants of this project are ten $6^{\text {th }}$ graders in a public secondary school selected with a random sampling method. At the beginning of the project, researchers asked to the learners about social media considerations, what social media tools were and how often they used social media. In the process of the study, participants used the Louisiana Channel and Art21 channels on YouTube to watch artist Julie Mehretu's videos about her workshops and actual works performances. Following this implementation, researchers interviewed the learners about the course. As a result of this project, it is assumed that learners will have more active participation in the course by using social media and learners would have more positive views on using social media tools in visual arts courses. In addition, it was concluded that getting to know contemporary artists and looking at their works in detail contributed to children's artistic perspectives.
\end{abstract}

Keywords: Contemporary Artist, Visual Arts Education, Social Media Tools, YouTube, Technology in Education

(c) 2021 idil. Bu makale Creative Commons Attribution (CC BY-NC-ND) 4.0 lisansı ile yayımlanmaktadır.

\footnotetext{
1 This study was presented as an oral presentation at the European Regional InSEA Congress, Helsinki, Finland, 18-21 June 2018
} 


\section{Introduction}

Today's education system needs to develop new teaching methods to meet the needs of the current time and to address the complex nature of the emerging problems, to keep up with the challenges of multidimensional social reality. Interdisciplinary approaches and new technologies in education aim to find answer to this need by breaking the one-dimensional thinking into patterns and disseminating the information (Kampouropoulou, Athanasiadis and Stefanos, 2011). In the early 00's students needed to discuss and choose the subject with the help of contemporary informatics solutions. Since YouTube was founded in 2005, videos as social media tools have found a common place for young people as a solution to this quest. Video channels give an opportunity to reach a variety of informational videos for a wide variety of purposes and also provide many conveniences for educational purposes (Gladysheva, Verboom \& Arora, 2014). Social media has changed the structure of learning and teaching environments. By providing free access to almost all social media tools, it has also facilitated access to larger audiences without time and space boundaries.

New technologies and social media tools can be used in the case of projects that combine theory and teaching practice. "Social change, the increasing trend of globalization, the multicultural reality as well as the intense competitive spirit which is spreading in all fields, call for the redefinition of the role of education, having as an ultimate goal the shaping of a strong educational environment which will be able to contribute to the balanced development of the students in real life" (Matsagouras, 2003; Kampouropoulou, Athanasiadis and Stefanos 2011: 61). The technology has democratized the self-expression for people and it happens with social media. "Participation through and with social media is an opening for teens to socially relate with each other in new contexts not limited to school, home, or a fixed time. Participation with and through social media is not limited to building social relationships; it can also be driven by specific interests of users" (Ito, Horst, Bittanti, HerrStephenson \& Lange; Castro, 2012: 153). Consequently, it's hard to ignore the power of new technologies and social media in art education.

The participants of this study are students studying in a public secondary school. In addition, many Syrian and Iranian refugee and migrant children are enrolled in the same school. Before we decided to conduct this study, we realized some communication problems of between refugee or immigrant students and local students in classes. The source of this communication problems are much related to the fact that refugee and immigrant students cannot speak Turkish and locals do not know how to live with different nationalities upon our observations. Therefore, this study was conducted with the purpose of shaping the understanding of each other and the boundaries of spaces. Each group of participants included both local students and immigrant or refugees. However, it is needed to be mentioned that most of the students at the research school do not want to take art course because of religious sensitivities. This fact affected their positions for the study as well. The ten students participated in the study were the most volunteering ones among the others. This study was carried out in the context of out-of-school learning with students who volunteered in the after-school visual arts course.

\section{Contemporary Artist: Julie Mehretu}

Julie Mehretu makes large-scale, gestural paintings that are built up through layers of acrylic paint on canvas overlaid with mark-making using pencil, pen, ink and thick streams of paint. Mehretu's work conveys a layering and compression of time, space and place (Berggruen Gallery). For Mehretu, abstraction "allows for thinking of an issue from different perspectives, from many points of view." She says "I work with source material that I am interested in conceptually, politically, or even just visually. I pull from all of this material, project it, trace it, break it up, recontextualize it, layer one on the other, and envelop it into the DNA of the painting. It then becomes the context, the history, the point of departure. It becomes the place of the painting" (Gallery label from Multiplex: Directions in Art, 2008). According to Ljungberg's (2009: 314) description "The radical quality of Mehretu's work is that the diagrammatic experimentation within her excentric and unbounded cartographies of an uncertain future suggests poetic ways for agents to alter a chaotic present by creating new sensibilities and sensualities that do not rely on consumerism or capitalism but are built on collective actions and desire for social change."

In this study, we used Julie Mehretu as the main artist subject. Mehretu has densely layered abstract paintings and prints. She is best known for her large-scale paintings that take the abstract energy, topography, and sensibility of global urban landscapes as a source of inspiration. One of the most important reasons for choosing 
Mehretu is related to her uses of different layers, different subjects and referring to visual collaboration and mutual understandings.

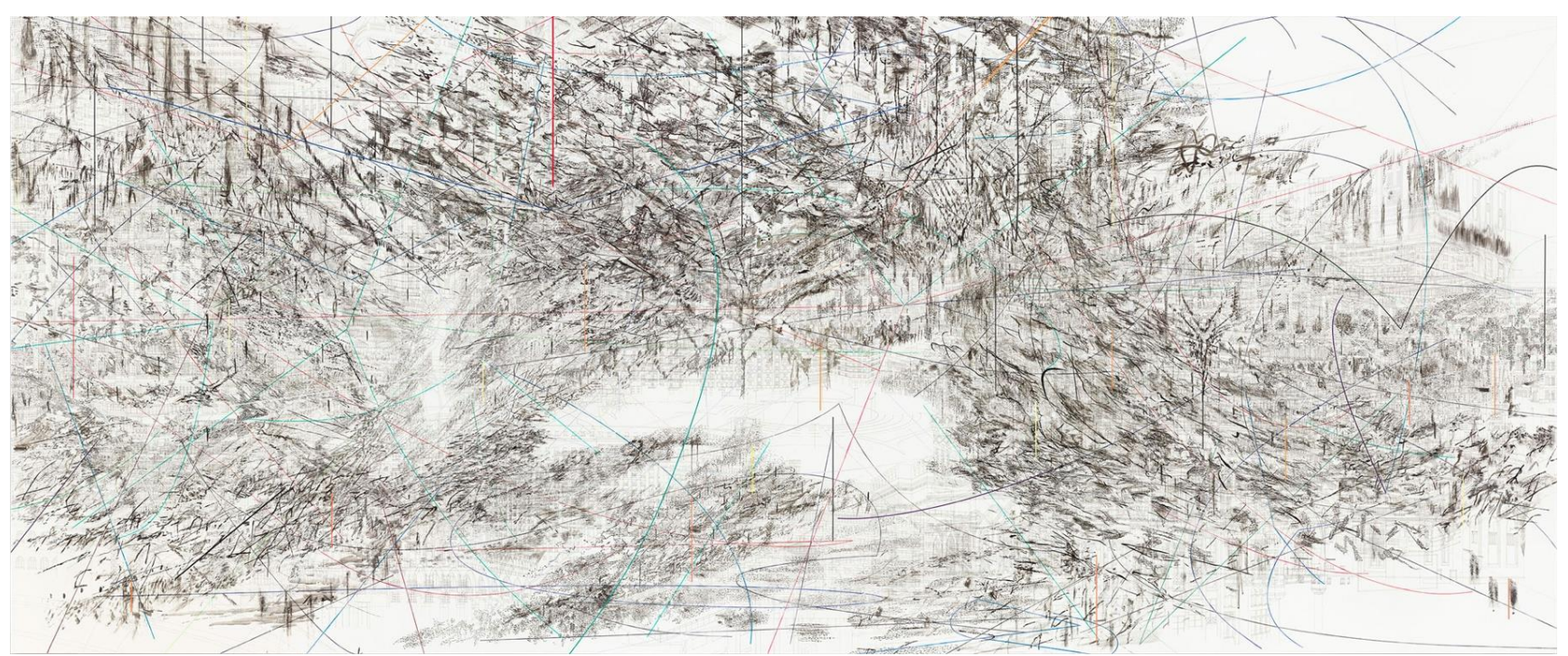

Figure 1: Cairo, 2013, Accession Number: F-MEHR-2013.024, https://www.thebroad.org/art/julie-mehretu/cairo

"The subject of this painting-drawing hybrid is Istanbul, a city perched on the border between Europe and Asia. The large scale of the work captures the epic dimension of the site, which was the capital of the Roman, Byzantine, and Ottoman empires. The Hagia Sophia - an Eastern Orthodox church converted to a mosque, then to a museum-occupies the quiet center of this frenzied metropolis." (The Museum of Modern Art, MoMA, 2007: 203). Istanbul is one of the biggest and cosmopolite city in Turkey. Therefore, it was important for us to talk about the work called "Empirical Construction, Istanbul" in the study. This painting was the main philosophical frame for our project.

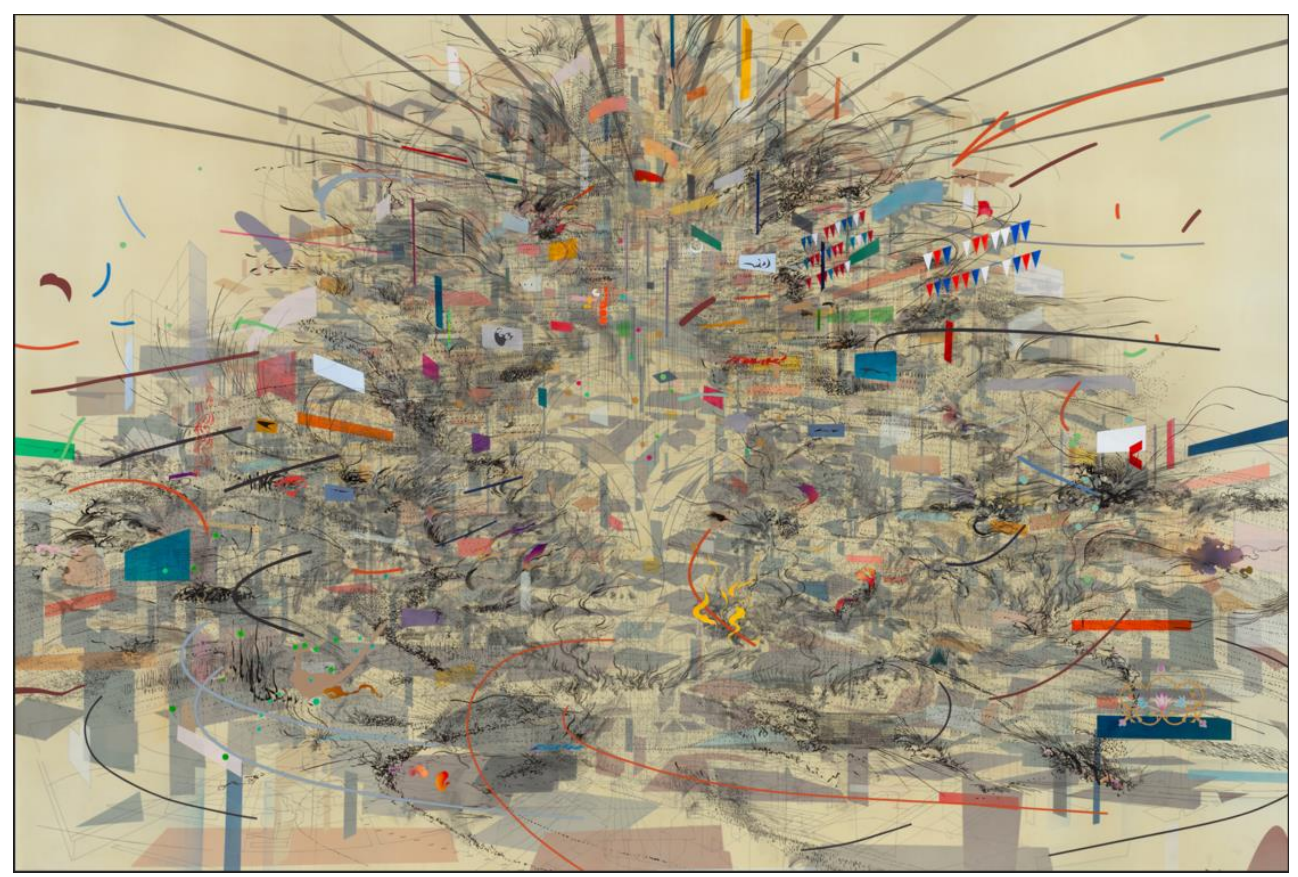

Figure 2: Empirical Construction, Istanbul, 2003, MoMA 


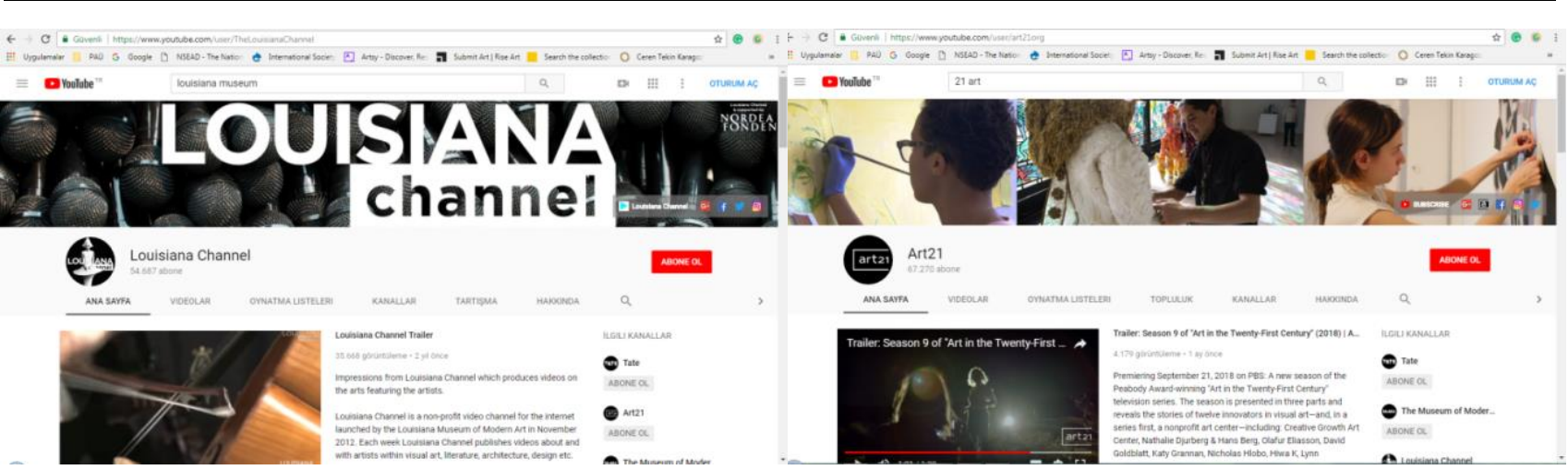

Figure 3: Louisiana Channel and Art21 channels on YouTube

During the activity, learners used the Louisiana Channel and Art21 channels on YouTube to see Mehteru's videos about her workshops and actual work performances and also, we checked the Instagram pages to see latest posts about the artist. After watching Mehretu's interviews on YouTube, we made some conversations with students about the artist's art and working style.

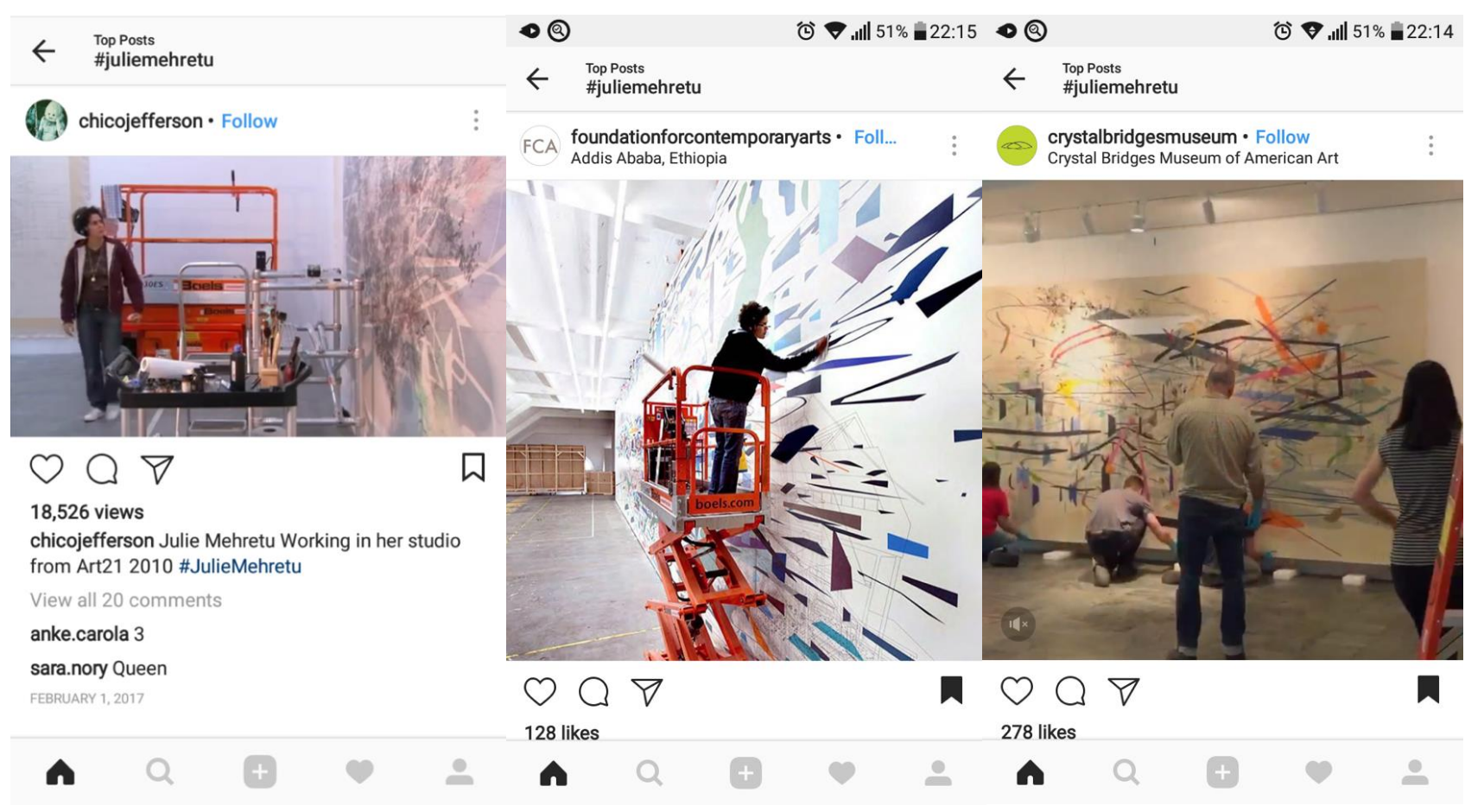

Figure 4: Some Instagram pages we used in the project

Participants were divided into groups during the implementation of the project. Before beginning of the study, group members made some plans and tried to understand each other by mostly using Google translate. Participants were asked to build a new city of their own and to include the sections they would need in a city. The members of the groups had to make common decisions in urban planning and in creating their own special areas. They had to persuade each other to create the areas, buildings, institutions in the city they wanted. 


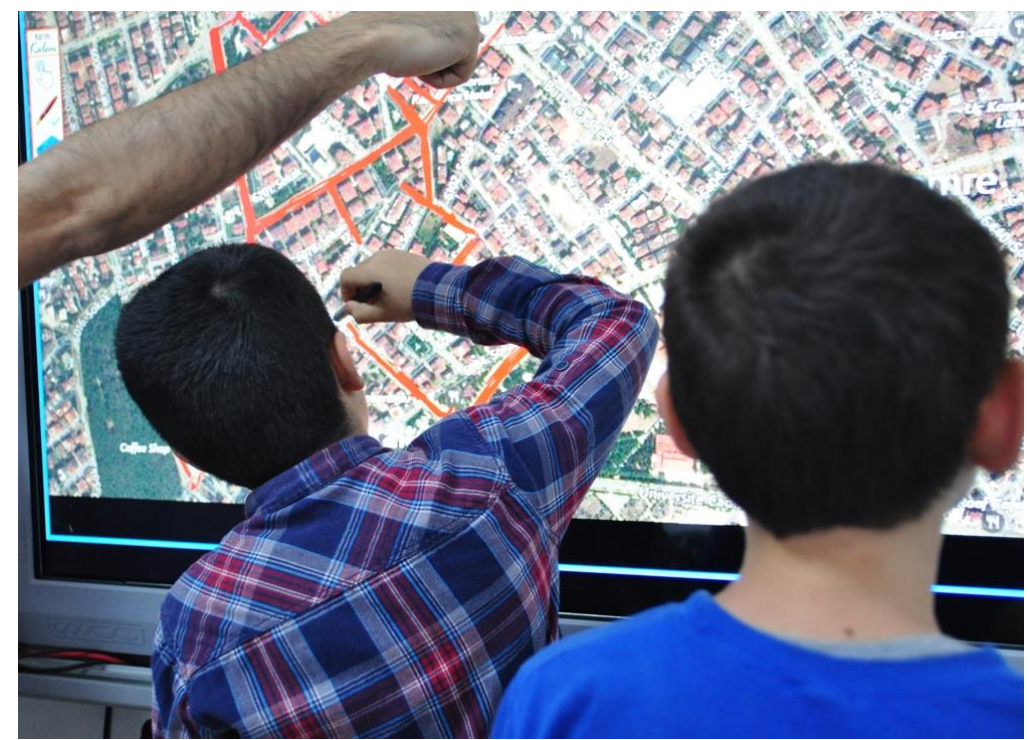

Figure 5: Participants using google maps with interactive board

Participants used Google maps, Microsoft paint and papers for making their ideas clear for the group members. Some participants searched a new place where they can live together, to have their own worlds on google maps. During the project, participants created their own cities. They made what they want to and where they want to live. They used layers for not get into others special places and they made a cooperation with other groups. They made some lines, layers and places for living and used pictograms because pictograms gave them the same visual language. The plans they made changed a lot during the process. But we said they could find some new ways if they tried some more.

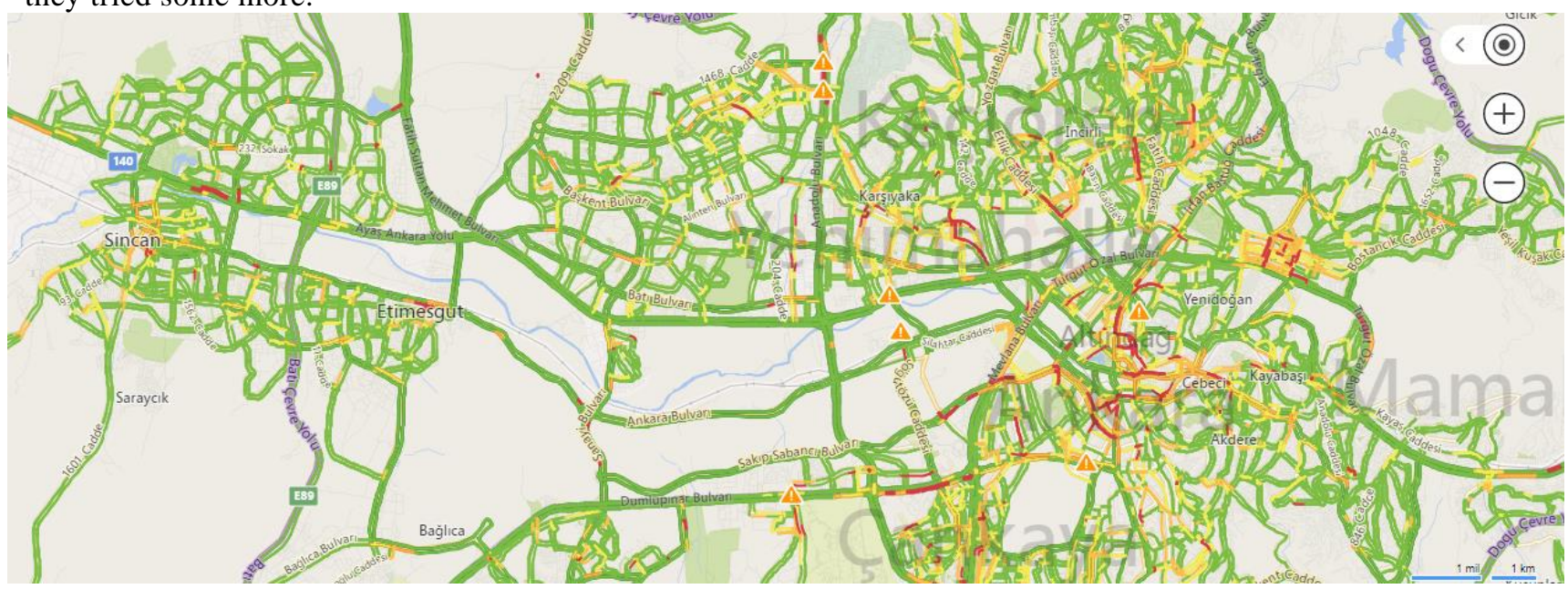

Figure 6: Google maps which used by Participants

At the end of the study, we interviewed with participants about how they felt about the cities they created together. Participants' thoughts about the project are as in the followings:

Participant 1: "I think it was a lot of fun. I learned my skills in this project and enjoyed very much. I think we should do the project again because I had so much fun. The videos and visuals I saw impressed me. For example, I liked the flag pictures and it was very useful because the videos and images we used were more effective. After the project, I think my skills towards the visual arts course have improved. Now I'm painting a little more beautiful." 
Participant 3: "I absolutely liked many beautiful pictures from this project. We learned to work together on this project. I would love to do it next year. The videos and images which shown us impressed me. I'm looking at the videos to make the pictures that I cannot do. I think it's helpful to use social media tools like YouTube and Instagram because we are looking at what we cannot do, we look at new artists in detail."

Participant 5: "It was a very nice work. It was fun. I had good time while doing the activity. We made a lot of fun pictures by combining our very nice ideas together. I would love to have the project do again. Using social media tools such as YouTube and Instagram has contributed a lot to my images and the information I don't know, I think it's a good learning resource."

Participant 9: "I enjoyed the project I participated in. I did not think I could make a big picture, which surprised me. I've seen one of the greatest painters the world will ever have and how she works. I wanted everyone to see this artist. At first, I did not believe that she was painting by herself. Therefore, watching the video made me believe that. The videos I watched developed my paintings and increased my belief in myself. Now, I can think more comfortable about art. We worked together with my classmates whom I could not speak in the same language. This made me very happy."

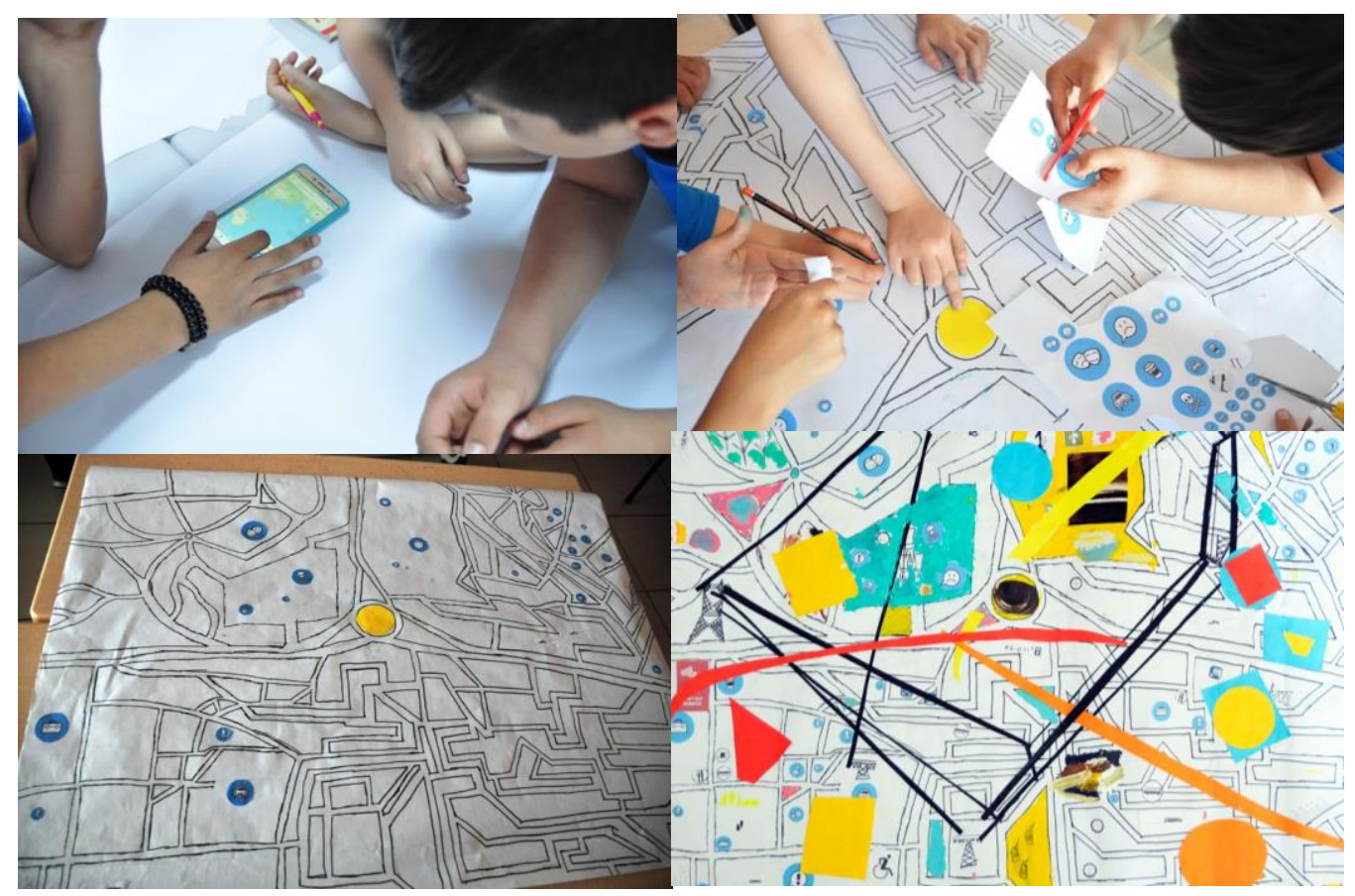

Figure 6: Event photos of the first group 


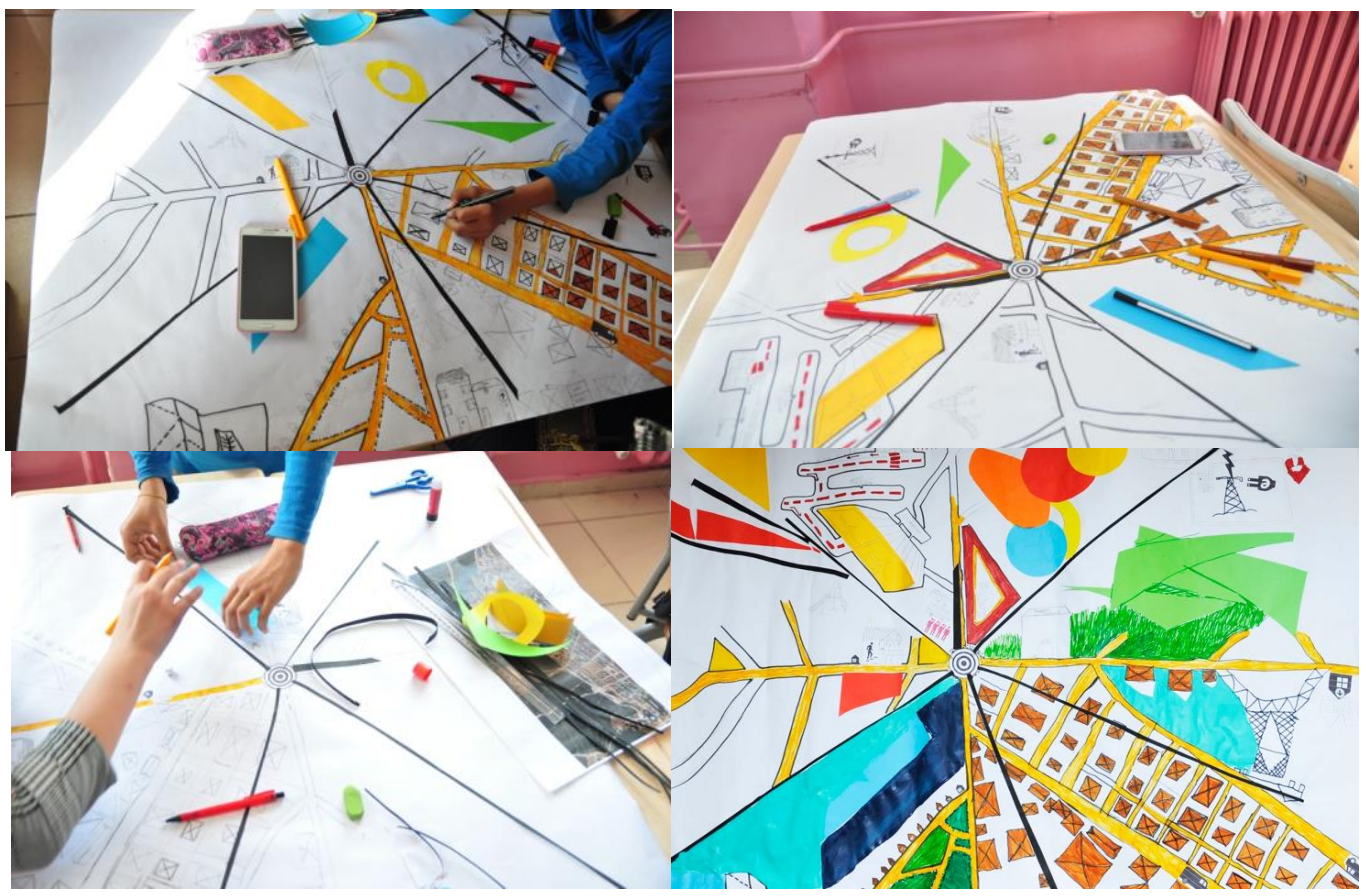

Figure 6: Event photos of the second group

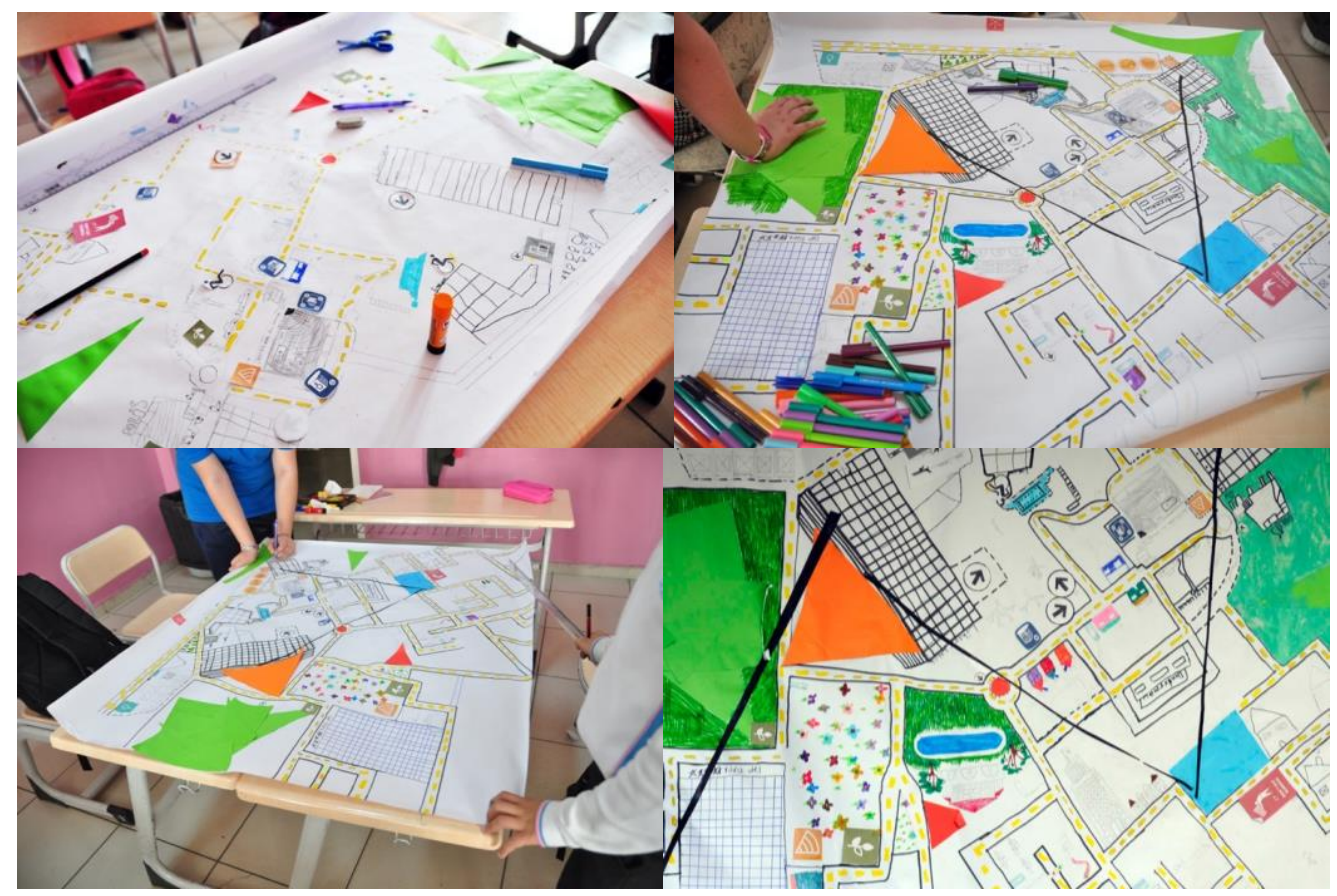

Figure 7: Event photos of the third group 


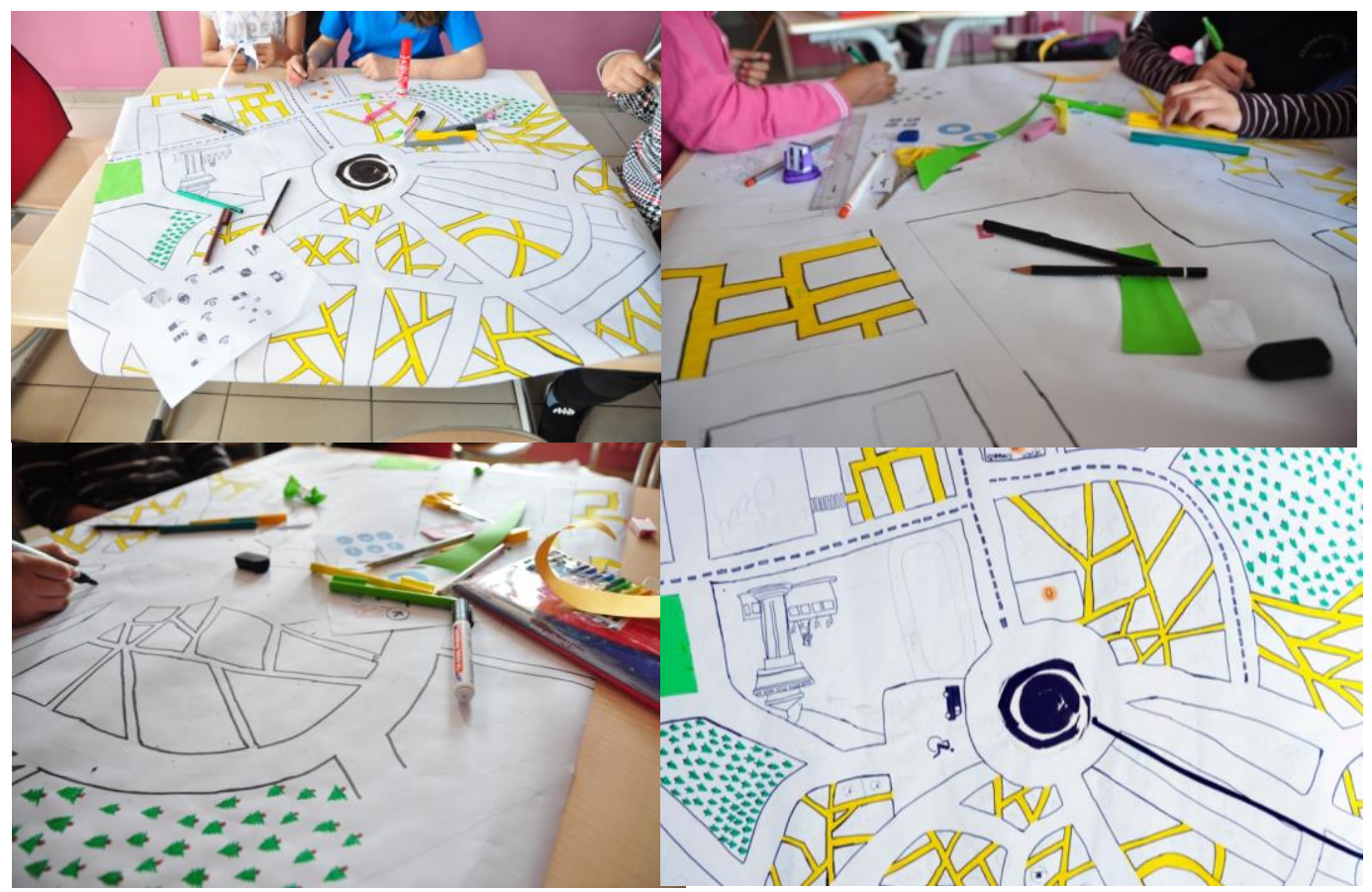

Figure 6: Event photos of the forth group

\section{Outcomes}

As researchers, we think that group activities with technology and social media tools have a huge impact on children's creativity and communication skills. As a result of this project, it is assumed that learners will have more active participation in the course by using social media and learners would have more positive views on using social media tools in visual arts courses. Kampouropoulou, Athanasiadis and Stefanos (2011) research also showed that the majority of the students is positive towards use of New Technologies in Art education and believes that introduction to new technology methods in Art education can be implemented in schools. Similarly, Sarsar, Basbay, Basbay (2015) stated that social media is efficient and necessary for teaching and learning process. They concluded that social media tools are motivating in class, providing a learning environment and supporting self-confidence of learners. In addition, many studies (Roblyer, McDaniel, Webb, Herman ve Witty, 2010; Matsagouras, 2012; Castro, 2012) have been reported that learners evaluate social media use positively in the learning process. Also, the children who did not care about arts started to interest, they connected arts with the way they love to use something in their daily lives like YouTube and there were no differences among students because they all knew how to use this tool. 


\section{References}

Castro, J. Carlos. Learning and Teaching Art through Social Media, Studies in Art Education, 53 (2), 2012, 152-169. http://dx.doi.org/10.1080/00393541.2012.11518859

Athanasiadis, Ilias \& Maria, Kampouropoulou \& Stefos, Efstathios. Students' views on the use of new technologies in art aducation: an interdisciplinary approach to higher education. Review of European Studies, 3 (1), 2011, 60-70.

Ljungberg, Christina. Cartographies of the Future: Julie Mehretu's Dynamic Charting of Fluid Spaces. The Cartographic Journal, 46(4) 2009, 308-315.

Matsagouras, Elias. Interdisciplinarity and Cross-thematic Curricula: Ways of organizing school knowledge. Review of Educational Affairs, 7, 2002, 19-36.

Roblyer, M. D., McDaniel, Michelle, Webb, Marsena, Herman, James, \& Witty, James. Findings on Facebook in higher education: A comparison of college faculty and student uses and perceptions of social networking sites. The Internet and Higher Education, 13 (3), 2010, 134-140.

Sarsar, Fırat, Başbay, Makbule \& Başbay, Alper. (2015) Use of Social Media in Learning and Teaching Process. Mersin University Journal of the Faculty of Education, Vol. 11, Issue 2. 2015. http://dx.doi.org/10.17860/efd.98783

\section{Websites}

Gallery label from Multiplex: Directions in Art, 1970 to Now, November 21, 2007-July 28, 2008. https://www.moma.org/collection/works/91778 Erişim tarihi: 03.08.2020

Publication excerpt from The Museum of Modern Art, MoMA Higlights since 1980, New York: The Museum of Modern Art, 2007, p. 203. https://www.moma.org/collection/works/91778 Erişim tarihi: 15.04.2021

Berggruen Gallery, Julie Mehretu Biography, https://www.berggruen.com/artists/julie-mehretu Erişim tarihi: 15.04.2021 


\title{
MEKÂNLARIN SINIRLARINI VE BİRBIRINİ ANLAMAK: SOSYAL MEDYA ARAÇLARI VE GÖRSEL SANATLARDA BİR ÇAĞDAŞ SANATÇI
}

\author{
Ceren Tekin Karagöz \\ İbrahim Karagöz
}

ÖZET

$\mathrm{Bu}$ makale, görsel sanatlar derslerinde kullanılan yöntemlerden biri olarak sosyal medya araçlarının ve çağdaş sanatçının öğrencileri ve ders sürecini nasıl etkilediğine odaklanmaktadır. Bu projenin katılımcıları, tesadüfi örnekleme yöntemiyle seçilen bir devlet ortaokulundaki on altıncı sınıf öğrencisidir. Projenin başında araştırmacılar öğrencilere sosyal medya ile ilgili düşünceleri, sosyal medya araçlarının neler olduğunu ve sosyal medyayı ne sıklıkla kullandıklarını sordular. Çalışma sürecinde katılımcılar, sanatçı Julie Mehretu'nun atölye çalışmaları ve gerçek iş performansları ile ilgili videolarını izlemek için YouTube'daki Louisiana Kanalı ve Art21 kanalları kullanılmıştır. Bu çalışma ile öğrencilerin sosyal medyayı kullanarak derse daha aktif katılım sağlayacağı ve görsel sanatlar derslerinde sosyal medya araçlarını kullanma konusunda öğrencilerin daha olumlu görüşlere sahip olacağı sonucuna ulaşılmıştır. Ayrıca güncel sanatçıları tanımanın ve eserleri üzerine deinlemesine bakmanının çocukların sanatsal bakış açılarına katkısı olduğu sonucuna da ulaşılmıştır.

Anahtar Kelimeler: Çağdaş sanatçı, görsel sanatlar eğitimi, sosyal medya araçları, YouTube, eğitimde teknoloji 